Research Article

\title{
Cooperative Governance of Complex Public-Private Partnership Program: Case Study of Characteristic Town Program
}

\begin{abstract}
Zhen Chen
School of Economics \& Management \& Engineering, Beijing University of Architecture \& Civil Engineering, Beijing 100044, China

Correspondence should be addressed to Zhen Chen; cz0021@126.com

Received 21 August 2020; Revised 19 October 2020; Accepted 7 November 2020; Published 14 December 2020

Academic Editor: Loke Foong

Copyright (C) 2020 Zhen Chen. This is an open access article distributed under the Creative Commons Attribution License, which permits unrestricted use, distribution, and reproduction in any medium, provided the original work is properly cited.

PPP program is characterized by great organizational complexity, complicated communication network, and high coordination cost, which lead governance problems to be more complex than usual construction projects. Investigating 49 stakeholders of the $\mathrm{D}$ characteristic town construction program, the author constructs the work interaction network and supervision network of characteristic town PPP program based on organizational relationship. Through the calculation and comparison of network parameters, the network problems were analyzed, and the governance improvement scheme was proposed. The results show that, during the construction phase of the PPP program, (1) the SPV is still the core stakeholders; (2) the PPP program supervison belongs to hierarchical supervision characteristics and (3) the government regulators and loan institutions have limited influences on the program but they can restrict the SPV by strengthening supervision with subprogram stakeholders.
\end{abstract}

\section{Introduction}

Complex programs have two meanings. One is called megaprojects which involve complex process and major undertaking [1]; the other means the set of numerous projects, which is time-parallelly constructed in the small area [2]. In recent years, the Chinese complex program has developed rapidly, just like Hong Kong-Zhuhai-Macau Bridge, Beijing Daxing International Airport. From these practices, the organizational complexity has been an important topic of research and practice [3] and dealing with organizational conflict plays an important role in organizational complexity [4]. Despite the significant development of project governance tools and techniques to facilitate project stakeholders' relationship improvement over a year [2], core stakeholders still could not control the project effectively.

Program governance (PG), viewed as the relations between project managers, board, owners, and other stakeholders, functions as an overall business for providing the framework of project organizational processes, decision- making simulation, and project management tools, which enables the successful delivery, programs, and portfolios of projects [5]. Public-Private Partnership (PPP) programs involve multiple owners (e.g., project owner and sub-project owner) and these stakeholders have a conflict of interest. Therefore, how to coordinate the relations among internal owners and the relations between owners and other stakeholders plays a key role in the delivery of projects [6]. Indeed, some PPP projects failed due to the contradictions of owners. For example, the Fourth Minjiang River Bridge PPP projects, located in Fuzhou, China, failed due to the fierce conflicts of the governments and Special Purpose Vehicles (SPV) of PPP projects. The government cannot guarantee the uniqueness of the bridge operation or fulfill the promise of repurchasing management right during operation period. As another example, Yiwei Expressway PPP projects, invested by Chengdu Road \& Bridge Engineering Co., Ltd., failed due to downtime caused by limited financing resources. Besides, the significant difference between regional development PPP projects and traditional PPP projects lies 
in its overall contracting of the program mostly. In other words, there exist packages of commonweal items and operational items in the regional development PPP projects. Because of lacking communication, cooperation, and compensation mechanisms, conflicts occurred with different sub-project owners. Therefore, project governance, under a complex environment, is necessary to constrain the responsibilities of stakeholders and ensure project effectiveness in regional development PPP projects.

\section{Literature Review}

More recent attention has been focused on PG. The research on stakeholder governance (SG) encompasses the power and incentive relationship of stakeholders, to evaluate and identify stakeholders' influences on project decision-making [7]. According to the hierarchy of construction projects, three main governance models, namely, vertical governance, horizontal governance, and project managers' governance, have been classified and the contractual governance and relational governance are the two main models according to information channels of construction projects [8]. Therefore, SG of the construction project is subordinate to the horizontal governance models based on the hierarchy [9] and is subordinate to the contractual governance and relational governance models from the perspectives of information channels [10]. Henisz et al. [11] noted that project governance was the external representation of the project relationship contracts. Too and Weaver [12] proposed the project governance framework based on the project organization. Rowley [13] discovered the influences of stakeholders in social networks which comes from their power, connections, and interests, etc. Previous studies have revealed the stakeholder governance results based on network property considering the dynamic factors. Yang and Zou [14] analyzed the stakeholder-associated risks in complex projects using Social Network Analysis (SNA) and opined that the risks were associated with internal and external project stakeholders and could transmit and amplify across the organization. Wang et al. [15] concluded that the character of stakeholders-network has impacts on performance. Klijn et al. [16] demonstrated the uncertainty of the project governance network and the effect of its trust on performance. Several scholars also discussed the importance of specific objects in the network based on governance relationships network. Ding et al. [17] pointed out that the project supervisor, as an independent decision-making body, played a minor role in projects compared with owners and constructors. Nevertheless, the project supervisor can help owners or constructors manage projects when they ally with owners or constructors. Wang et al. [18] also viewed that the project relying on the project manager excessively made the project and its manager encounter more governance risks, and determined the solutions including decentralization of power and networked information channels. Other scholars focused on the areas of organizational power, communication, and governance pattern of projects using a case study. Lienert et al. [19] and Wei [20] conducted the case study of water plant project and expressway project, respectively, and expressed complex interrelationships among stakeholders.

The existing research primarily revolves around three aspects: dynamic impact, stakeholders' role, and the governance patterns of the complete network power communication. However, for complex regional development PPP program organizations, characterized by program and PPP project organization, there is limited systematic quantitative analysis of stakeholders' influence and its effective power and communication, nor clear deconstruction of the coordination and conflict relationships of PPP program organization. The stakeholders of megaprojects are inclined to adopt the way of combining formal contractual relationships and informal relationships to address the barriers encountered within the program [21]. Therefore, as a case study of D characteristic town's regional development PPP projects, this paper first constructed indicators to display the internal links among organizations and developed social networks to represent them. Then, the cooperation and supervision relationships were identified among PPP project organizations to degrade the complexity of the program. Finally, the key stakeholder was determined and their influence degree and its impact path were clarified, which offers suggestions for prompting project governance.

\section{Methodology}

3.1. Definition of Network Boundary and Stakeholder Influence. Stakeholders from organizations can maximize their performance only when they are in the best position of the organizational network [13]. The boundary of the network in this study is limited in the stakeholder organization field including the owners, supervisors, and participants in the regional development PPP project, and furthermore the relationships between stakeholders are discussed. From the perspective of network subject, the stakeholders of the PPP project include government parties, private partners, SPV, contractors, suppliers, operators, financing parties, and others. According to the actual situation of this study, the stakeholders include 49 subjects, as shown in Table 1. Using existing research results on stakeholders' relationships and based on different relation purposes, a two-dimensional network structure was developed according to work demands of communication and supervision for all the stakeholders. The two-dimensional network structure is as follows:

(1) Communication and Cooperation Networks (CCNs). They refer to the relationship network formed by communication and cooperation within the project organization, which transmits the official information, unofficial information, instructions, knowledge, and experience through formal and informal channels.

(2) Supervisory Relationship Networks (SRN). Based on the statutory and regulatory requirements and project management demands, the relationship network of work supervision, review, and inspection is conducted for regulated parties. 
TABLE 1: CCN and SRN centrality degree.

\begin{tabular}{|c|c|c|c|c|c|c|c|c|c|c|}
\hline \multirow[b]{2}{*}{ Types of stakeholders } & \multicolumn{5}{|c|}{$\mathrm{CNN}$} & \multicolumn{5}{|c|}{ SRN } \\
\hline & DC & $\begin{array}{c}\text { Weighted degree } \\
\text { centrality } \\
\text { (WDC) }\end{array}$ & CC & $\mathrm{BC}$ & $\mathrm{EC}$ & DC & $\begin{array}{l}\text { Weighted degree } \\
\text { centrality } \\
\text { (WDC) }\end{array}$ & CC & $\mathrm{BC}$ & $\mathrm{EC}$ \\
\hline Private partner & 2 & 4 & 0.396694 & 0 & 0.097775 & 1 & 2 & 0.286713 & 0 & 0 \\
\hline $\begin{array}{l}\text { Government } \\
\text { operations } \\
\text { management } \\
\text { company }\end{array}$ & 4 & 4 & 0.40678 & 22.333333 & 0.104307 & 2 & 3 & 0.286713 & 13.666667 & 0.007922 \\
\hline SPV & 44 & 83 & 0.648649 & 744.466667 & 1 & 8 & 13 & 0.392157 & 280 & 0.110452 \\
\hline $\begin{array}{l}\text { Local Bureau of } \\
\text { Finance }\end{array}$ & 4 & 4 & 0.40678 & 22.333333 & 0.104307 & 2 & 3 & 0.286713 & 13.666667 & 0.007922 \\
\hline $\begin{array}{l}\text { Local Development } \\
\text { and Reform } \\
\text { Commission }\end{array}$ & 4 & 4 & 0.40678 & 22.333333 & 0.104307 & 2 & 3 & 0.286713 & 13.666667 & 0.007922 \\
\hline Project leading group & 4 & 6 & 0.393443 & 21 & 0.097242 & 1 & 1 & 0.386139 & 0 & 0 \\
\hline Project headquarters & 32 & 73 & 0.6 & 191.466667 & 0.941944 & 16 & 26 & 0.612903 & 342 & 0.222899 \\
\hline $\begin{array}{l}\text { Designing unit of } \\
\text { project }\end{array}$ & 20 & 27 & 0.484848 & 62.5 & 0.60856 & 1 & 2 & 0 & 0 & 0.280442 \\
\hline Project contractor & 24 & 42 & 0.564706 & 74.433333 & 0.894066 & 3 & 5 & 1 & 0 & 0.541617 \\
\hline Project supervisor & 22 & 35 & 0.521739 & 63 & 0.776457 & 3 & 6 & 1 & 0 & 0.280442 \\
\hline Bank & 2 & 2 & 0.396694 & 0 & 0.097775 & 1 & 2 & 0.286713 & 0 & 0 \\
\hline $\begin{array}{l}\text { Other enterprises' } \\
\text { financial company }\end{array}$ & 2 & 2 & 0.396694 & 0 & 0.097775 & 1 & 1 & 0.286713 & 0 & 0 \\
\hline Project supplier & 22 & 33 & 0.521739 & 63 & 0.776457 & 3 & 5 & 0 & 0 & 1 \\
\hline $\begin{array}{l}\text { Management unit of } \\
\text { facilities }\end{array}$ & 2 & 2 & 0.396694 & 0 & 0.097775 & 1 & 1 & 0 & 0 & 0.214977 \\
\hline $\begin{array}{l}\text { Sewage waste } \\
\text { management } \\
\text { organization }\end{array}$ & 12 & 27 & 0.527473 & 44.133333 & 0.421171 & 5 & 8 & 1 & 40 & 0.280442 \\
\hline $\begin{array}{l}\text { Solid waste } \\
\text { management } \\
\text { organization }\end{array}$ & 12 & 27 & 0.527473 & 44.133333 & 0.421171 & 5 & 8 & 1 & 40 & 0.280442 \\
\hline $\begin{array}{l}\text { Water supply } \\
\text { organization }\end{array}$ & 12 & 27 & 0.527473 & 44.133333 & 0.421171 & 5 & 8 & 1 & 40 & 0.280442 \\
\hline Heating organization & 12 & 27 & 0.527473 & 44.133333 & 0.421171 & 5 & 8 & 1 & 40 & 0.280442 \\
\hline $\begin{array}{l}\text { Gas supply } \\
\text { organization }\end{array}$ & 12 & 27 & 0.527473 & 44.133333 & 0.421171 & 5 & 8 & 1 & 40 & 0.280442 \\
\hline $\begin{array}{l}\text { Utility tunnel } \\
\text { management } \\
\text { organization }\end{array}$ & 12 & 27 & 0.527473 & 44.133333 & 0.421171 & 5 & 8 & 1 & 40 & 0.280442 \\
\hline $\begin{array}{l}\text { Designer of sewage } \\
\text { waste facilities }\end{array}$ & 18 & 22 & 0.432432 & 27.933333 & 0.458922 & 1 & 2 & 0 & 0 & 0.261174 \\
\hline $\begin{array}{l}\text { Contractor of sewage } \\
\text { waste facilities }\end{array}$ & 22 & 38 & 0.505263 & 53.533333 & 0.718478 & 3 & 5 & 1 & 0 & 0.466305 \\
\hline $\begin{array}{l}\text { Supervisor of sewage } \\
\text { waste facilities }\end{array}$ & 20 & 31 & 0.466019 & 30.133333 & 0.612794 & 3 & 6 & 1 & 0 & 0.261174 \\
\hline $\begin{array}{l}\text { Supplier of sewage } \\
\text { waste facilities }\end{array}$ & 20 & 30 & 0.466019 & 30.133333 & 0.612794 & 3 & 5 & 0 & 0 & 0.818012 \\
\hline $\begin{array}{l}\text { Designer of solid waste } \\
\text { facilities }\end{array}$ & 18 & 22 & 0.432432 & 27.933333 & 0.458922 & 1 & 2 & 0 & 0 & 0.261174 \\
\hline $\begin{array}{l}\text { Contractor of solid } \\
\text { waste facilities }\end{array}$ & 22 & 38 & 0.505263 & 53.533333 & 0.718478 & 3 & 5 & 1 & 0 & 0.466305 \\
\hline $\begin{array}{l}\text { Supervisor of solid } \\
\text { waste facilities }\end{array}$ & 20 & 31 & 0.466019 & 30.133333 & 0.612794 & 3 & 6 & 1 & 0 & 0.261174 \\
\hline $\begin{array}{l}\text { Supplier of solid waste } \\
\text { facilities }\end{array}$ & 20 & 30 & 0.466019 & 30.133333 & 0.612794 & 3 & 5 & 0 & 0 & 0.818012 \\
\hline $\begin{array}{l}\text { Designer of water } \\
\text { supply facilities }\end{array}$ & 18 & 22 & 0.432432 & 27.933333 & 0.458922 & 1 & 2 & 0 & 0 & 0.261174 \\
\hline $\begin{array}{l}\text { Contractor of water } \\
\text { supply facilities }\end{array}$ & 22 & 38 & 0.505263 & 53.533333 & 0.718478 & 2 & 3 & 1 & 0 & 0.261174 \\
\hline
\end{tabular}


TABLE 1: Continued.

\begin{tabular}{|c|c|c|c|c|c|c|c|c|c|c|}
\hline \multirow[b]{2}{*}{ Types of stakeholders } & \multicolumn{5}{|c|}{$\mathrm{CNN}$} & \multicolumn{5}{|c|}{ SRN } \\
\hline & $\mathrm{DC}$ & $\begin{array}{c}\text { Weighted degree } \\
\text { centrality } \\
\text { (WDC) }\end{array}$ & CC & $\mathrm{BC}$ & EC & DC & $\begin{array}{c}\text { Weighted degree } \\
\text { centrality } \\
\text { (WDC) }\end{array}$ & $\mathrm{CC}$ & $\mathrm{BC}$ & $\mathrm{EC}$ \\
\hline $\begin{array}{l}\text { Supervisor of water } \\
\text { supply facilities }\end{array}$ & 20 & 31 & 0.466019 & 30.133333 & 0.612794 & 3 & 6 & 1 & 0 & 0.261174 \\
\hline $\begin{array}{l}\text { Supplier of water } \\
\text { supply facilities }\end{array}$ & 20 & 30 & 0.466019 & 30.133333 & 0.612794 & 3 & 5 & 0 & 0 & 0.671436 \\
\hline $\begin{array}{l}\text { Designer of heating } \\
\text { systems }\end{array}$ & 18 & 22 & 0.432432 & 27.933333 & 0.458922 & 1 & 2 & 0 & 0 & 0.261174 \\
\hline $\begin{array}{l}\text { Contractor of heating } \\
\text { systems }\end{array}$ & 22 & 38 & 0.505263 & 53.533333 & 0.718478 & 4 & 7 & 1 & 0 & 0.671436 \\
\hline $\begin{array}{l}\text { Supervisor of heating } \\
\text { systems }\end{array}$ & 20 & 31 & 0.466019 & 30.133333 & 0.612794 & 3 & 6 & 1 & 0 & 0.261174 \\
\hline $\begin{array}{l}\text { Supplier of heating } \\
\text { systems }\end{array}$ & 20 & 30 & 0.466019 & 30.133333 & 0.612794 & 3 & 5 & 0 & 0 & 0.964588 \\
\hline $\begin{array}{l}\text { Designer of gas supply } \\
\text { facilities }\end{array}$ & 18 & 22 & 0.432432 & 27.933333 & 0.458922 & 1 & 2 & 0 & 0 & 0.261174 \\
\hline $\begin{array}{l}\text { Contractor of gas } \\
\text { supply facilities }\end{array}$ & 22 & 38 & 0.505263 & 53.533333 & 0.718478 & 3 & 5 & 1 & 0 & 0.466305 \\
\hline $\begin{array}{l}\text { Supervisor of gas } \\
\text { supply facilities }\end{array}$ & 20 & 31 & 0.466019 & 30.133333 & 0.612794 & 3 & 6 & 1 & 0 & 0.261174 \\
\hline $\begin{array}{l}\text { Supplier of gas supply } \\
\text { facilities }\end{array}$ & 20 & 30 & 0.466019 & 30.133333 & 0.612794 & 3 & 5 & 0 & 0 & 0.818012 \\
\hline $\begin{array}{l}\text { Designer of utility } \\
\text { tunnel }\end{array}$ & 18 & 22 & 0.432432 & 27.933333 & 0.458922 & 1 & 2 & 0 & 0 & 0.261174 \\
\hline $\begin{array}{l}\text { Contractor of utility } \\
\text { tunnel }\end{array}$ & 22 & 38 & 0.505263 & 53.533333 & 0.718478 & 3 & 5 & 1 & 0 & 0.466305 \\
\hline $\begin{array}{l}\text { Supervisor of utility } \\
\text { tunnel }\end{array}$ & 20 & 31 & 0.466019 & 30.133333 & 0.612794 & 3 & 6 & 1 & 0 & 0.261174 \\
\hline $\begin{array}{l}\text { Supplier of utility } \\
\text { tunnel }\end{array}$ & 20 & 30 & 0.466019 & 30.133333 & 0.612794 & 3 & 5 & 0 & 0 & 0.818012 \\
\hline Government & 8 & 9 & 0.303797 & 9 & 0.044883 & 3 & 3 & 0.235294 & 0 & 0 \\
\hline $\begin{array}{l}\text { Designer of industrial } \\
\text { park road }\end{array}$ & 20 & 25 & 0.484848 & 62.5 & 0.60856 & 1 & 2 & 0 & 0 & 0.280442 \\
\hline $\begin{array}{l}\text { Contractor of } \\
\text { industrial park road }\end{array}$ & 24 & 39 & 0.564706 & 74.433333 & 0.894066 & 3 & 5 & 1 & 0 & 0.541617 \\
\hline $\begin{array}{l}\text { Supervisor of } \\
\text { industrial park road }\end{array}$ & 22 & 35 & 0.521739 & 63 & 0.776457 & 3 & 6 & 1 & 0 & 0.280442 \\
\hline $\begin{array}{l}\text { Supplier of industrial } \\
\text { park road }\end{array}$ & 22 & 29 & 0.521739 & 63 & 0.776457 & 3 & 5 & 0 & 0 & 1 \\
\hline
\end{tabular}

3.2. Network Index Selection. It is necessary to understand the network structure, describe the network characteristics, and describe the importance of stakeholders to reflect the pairwise relationships of stakeholders by appropriate network parameters. In this study, individual centrality was used for describing the influence of program stakeholders over other project stakeholders such as degree, closeness, betweenness, and eigenvector centrality.

Degree centrality (DC) is divided into in-degree centrality and out-degree centrality according to the vector pointing relationship of the directed network. In-degree centrality refers to incoming numbers of other nodes, which represents the frequency mentioned by other stakeholders in the questionnaire. Out-degree centrality refers to the outcoming numbers of this node, which reflects the frequency involving other stakeholders in the questionnaire. Degree centrality is measured by the weighted sum of in-degree and out-degree, as presented in

$$
C_{D}\left(n_{i}\right)=\frac{m m\left(n_{i}\right)}{N-1}
$$

where $N$ is the network size and $m m\left(n_{i}\right)$ is the number of links connected to node $n_{i}$.

Closeness centrality (CC) reflects the proximity between each node and each other node in the network, which focuses on the importance of each node to the central node. It can be measured by

$$
C_{C}\left(n_{i}\right)=\frac{N-1}{\sum_{j=1}^{n} d\left(n_{i}, n_{j}\right)},
$$


where $N$ is the network size and $d\left(n_{i}, n_{j}\right)$ is the shortest distance between node $n_{i}$ and node $n_{j}$.

Betweenness centrality $(\mathrm{BC})$ indicates the value of each node measured by the number of shortest paths through each node. It is given by equation (3).

$$
C_{B}\left(n_{i}\right)=\frac{\left(\sum_{j<k}^{i} g_{j k}\left(n_{i}\right)\right) / g_{j k}}{(N-1)(N-2)},
$$

where $N$ is the network size, $g_{j k}$ is the number of shortest paths from node $n_{j}$ to node $n_{k}$, and $g_{j k}\left(n_{i}\right)$ is the number of shortest paths considering actor $n_{i}$.

Eigenvector centrality (EC) focuses on the value of each node in the network. Each node centrality is positively impacted by its neighbor node centrality. It can be calculated by

$$
C_{E}\left(n_{i}\right)=c \sum_{j=1}^{n} a_{i j} x_{j}=c A x,
$$

where $c$ is a proportionality constant, $x_{i}$ is the importance of measurement of node $n_{i}$ and is noted as $x=\left[x_{1}, x_{2}, x_{3}, \ldots, x_{n}\right]^{T}$, and $x$ is the eigenvector corresponding to eigenvalue $c^{-1}[22]$.

3.3. Data Collection. Based on the above research, the data of stakeholders and their relationships were gathered considering the contractual and organizational relationship of D characteristic town. D characteristic town, covering an area of 6 square kilometers and located in Northeast China, revolved around the tourism and commercial service industry and adopted the Build-Operate-Transfer (BOT) model for operation. According to the PPP libraries from Wind databases that cover $26 \mathrm{PPP}$ projects at the execution stage, there are 17 projects developed with the BOT model, 2 projects developed with the BOT and Transfer-OperateTransfer (TOT) model, and 5 projects developed in other models. The case selected in this study is typical because it represents the mainstream operation mode of characteristic town PPP projects in China at this stage.

A questionnaire survey was then conducted to investigate the project participants' relationships. Questionnaires were distributed and filled out from private partners to the other 48 stakeholders of projects. Considering the research preciseness and data availability, each private partner provided two or three questionnaires and these questionnaires were filled out by different respondents. The relationship between each stakeholder and other stakeholders was reflected by questionnaires filled out by each stakeholder and their corresponding stakeholders, which considered all their possible connections. Also, the communication frequency and supervisory relationship between each stakeholder and other stakeholders were identified by the highest value about the communication frequency and supervisory relationship of questionnaires filled out by them which considered the different respondents' working conditions and null conditions. If the questionnaire has information about the relationship but no communication frequency or supervisory degree, it is viewed as a missing value. Otherwise, if the questionnaire has information about communication frequency or a supervisory degree but no relationship, it is defined as a link.

\section{Results}

4.1. Network Feature Analysis. The collected relationship dates from the questionnaires were analyzed using Social Network Analysis (SNA) software Gephi (0.9.2). The number of directed ties is 418 in CCN and 74 in SRN. The relation strength of CNN and SRN was defined using a Likert scale, which functions as the weight of network connections. For the relation of CNN between respondents and another stakeholder, "0" is viewed as no communication, "1" represents communication once a month, " 2 " represents communication once a week, " 3 " represents communication 2-3 times a week, and "4" represents communication more than once a day. For the relation of SRN between respondents and another stakeholder, " 0 " indicates that there is no supervision relation, " 1 " indicates that there exists a reporting relationship from another stakeholder to respondents, and "2" represents that the respondents supervise another stakeholder.

The results (see Table 2) show that the average degree and average weighted degree of $\mathrm{CCN}$ are significantly greater than those of SRN, which indicates the communication frequency is higher than supervisory frequency between stakeholders of the program and they can achieve the project goals through multi-relationship including formal relationships and informal relationships. The average weight of $\mathrm{CNN}$ is 1.610 and its weight interval ranged from 1 to 4 , which indicates that most of the communication frequency is low (once a month). The weighted average of SRN is 1.689 and its weight interval ranged from 1 to 2 , which represents that $68.9 \%$ of relations are supervision relationships, and $31.1 \%$ of relations are reporting relationships. In addition, the network diameter and average path length of $\mathrm{CCN}$ are smaller than those of SRN, which indicates that SRN, compared with $\mathrm{CNN}$, has more communication links, longer communication paths, and slower message passing.

4.2. Centrality Analysis. The visualization of $\mathrm{CCN}$ and SRN in the program was conducted using Gephi software. As shown in Figure 1, the network has 49 stakeholders (each is represented by a node). Each arrow from node A to node B represents the directed relations, including communication and cooperation relationships and supervision or reporting relationships. The thicker arrow lines indicate the higher weights of the relations. In addition, there is no arrow line under the condition of no relations.

The degree, weighted degree, closeness, betweenness, and eigenvector centrality of CCN and SRN were then measured (see Table 1). In CCN, firstly, the top three DC and WDC were the SPV, project headquarters, and project contractors, which indicates that the SPV and project headquarters are most closely connected with other project stakeholders. Compared with project headquarters, the SPV 
TABle 2: Project descriptive statistics.

\begin{tabular}{lcc}
\hline $\begin{array}{l}\text { Descriptive } \\
\text { statistical index }\end{array}$ & $\begin{array}{c}\text { Communication and } \\
\text { cooperation networks } \\
(\mathrm{CNN})\end{array}$ & $\begin{array}{c}\text { Supervisory } \\
\text { relationship } \\
\text { networks (SRN) }\end{array}$ \\
\hline $\begin{array}{l}\text { Average degree } \\
\text { Average }\end{array}$ & 8.531 & 1.510 \\
$\begin{array}{l}\text { weighted degree } \\
\text { Average weight }\end{array}$ & 13.735 & 2.551 \\
$\begin{array}{l}\text { Minimum value } \\
\text { Maximum }\end{array}$ & 1.610 & 1.689 \\
$\begin{array}{l}\text { value } \\
\text { Node number }\end{array}$ & 4 & 1 \\
$\begin{array}{l}\text { Number of ties } \\
\begin{array}{l}\text { Network } \\
\text { diameter }\end{array}\end{array}$ & 418 & 2 \\
$\begin{array}{l}\text { Average path } \\
\text { length }\end{array}$ & 4 & 49 \\
$\begin{array}{l}\text { Clustering } \\
\text { coefficient }\end{array}$ & 2.137 & 74 \\
\hline
\end{tabular}

manages projects and is closely connected with the government, finance, and supervision department, so the SPV will obtain more information. As the general contractor, the project contractor should not only complete their mission but also help contractors of subprojects fulfill their tasks, so the project contractors are regarded as the third connected stakeholders. Secondly, the top three of CC in CNN were also the SPV, project headquarters, and project contractor, which indicates that the SPV is on the shortest path to other stakeholders and thus they are able to communicate quickly and reduce information error under the same medium propagation condition. Thirdly, the top three of BC in CNN were the SPV, project headquarters, and contractor of the project and industrial park road, which indicates that the shortest messaging path between stakeholders is passed by the SPV, and the messaging efficiency, in theory, had insignificant difference through project contractor and contractor of the industrial park road. Finally, the top three of EC in CNN were also the SPV, project headquarters, and project contractor, which indicates that the maximum value, from the perspective of information transfer, was produced by the SPV followed by the project headquarters and project contractors.

In SRN, the top three DC and WDC are the project headquarters, SPV, sewage waste management, solid waste management, water supply, heating, gas supply, and utility tunnel management organization. The project headquarters function as the supervision of specific work because they manage the project construction in reality rather than SPV. In addition, several stakeholders' $\mathrm{CC}$ is 1 , including the contractor and supervisor of project, sewage waste management organization and contractor and supervisor of sewage waste facilities, solid waste management organization and contractor and supervisor of solid waste facilities, heating organization and contractor and supervisor of heating systems, gas supply organization and contractor and supervisor of gas supply facilities, utility tunnel management organization, and contractor and supervisor of a utility tunnel. In other words, these organizations have the shortest distance from other stakeholders and a single messaging path for supervision. Therefore, these organizations are suitable for straight linear demand. Compared with the above organizations, the project headquarters and SPV are in a disadvantaged position in terms of obtaining supervision information. The top three of BC in SRN were the project headquarters, SPV, and subprojects management organization including sewage waste management organization, solid waste management organization, water supply organization, heating organization, gas supply organization, and utility tunnel management organization. It indicates that the node named project headquarters is on the shortest path mostly for total supervising messages, followed by the SPV and subprojects management organization. Furthermore, the $\mathrm{BC}$ of the basic organization is 0 , which accords with the project's hierarchical supervision model.

4.3. Stakeholders' Influence Analysis. The stakeholders' influence is divided into work influence and authority influence according to the types of networks. The work influence represents the degree of communication and cooperation between stakeholders in CCN. The authority influence represents the power of stakeholders in SRN. The degree of influence was measured using the degree method and PageRank algorithm, respectively. For the method of degree, the higher out-degree indicates the greater power (impacted to), and the higher in-degree indicates the greater power (impacted by). PageRank algorithm was created by Larry Page to find the best webpages through clicking web search links, considering the number of links and influence of objects. The research results are shown in Table 3.

Based on the degree method, the greatest work influence (impacted to) is the SPV of the project followed by the project headquarters and contractor of the industrial park road, and the greatest of work influence (impacted by) is the SPV of the project followed by the project headquarters and project contractor. However, based on the method of PageRank algorithm, the greatest work influence (impacted to) is the private partner followed by project headquarters and contractor of the project and industrial park road. The results have no significant difference between the method of degree and PageRank algorithm, which shows that the SPV of the project is the most important node in $\mathrm{CCN}$, followed by the project headquarters. The project contractor is viewed as the third influential (impacted by) stakeholder because they have to manage the program and comply with various stakeholders' requirements. The contractor of the industrial park road is considered as the third influential (impacted to) stakeholder because they need the cooperation of various stakeholders.

Based on the degree method, the greatest authority influence (impacted to) is the project headquarters followed by sewage waste management organization, solid waste management organization, water supply organization, heating organization, and gas supply organization, and the greatest authority influence (impacted by) is the SPV followed by all suppliers. However, using the PageRank algorithm, the 


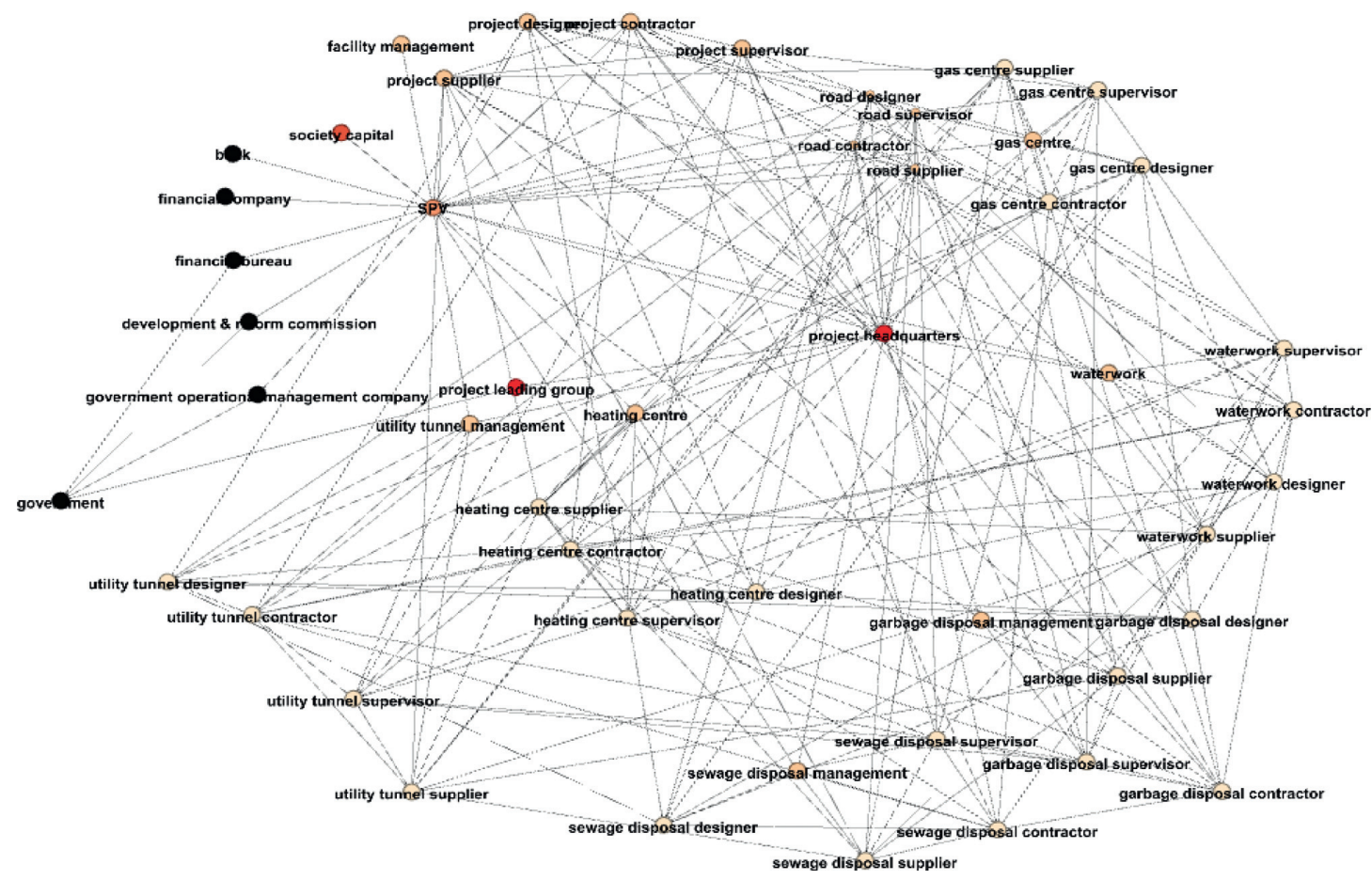

(a)

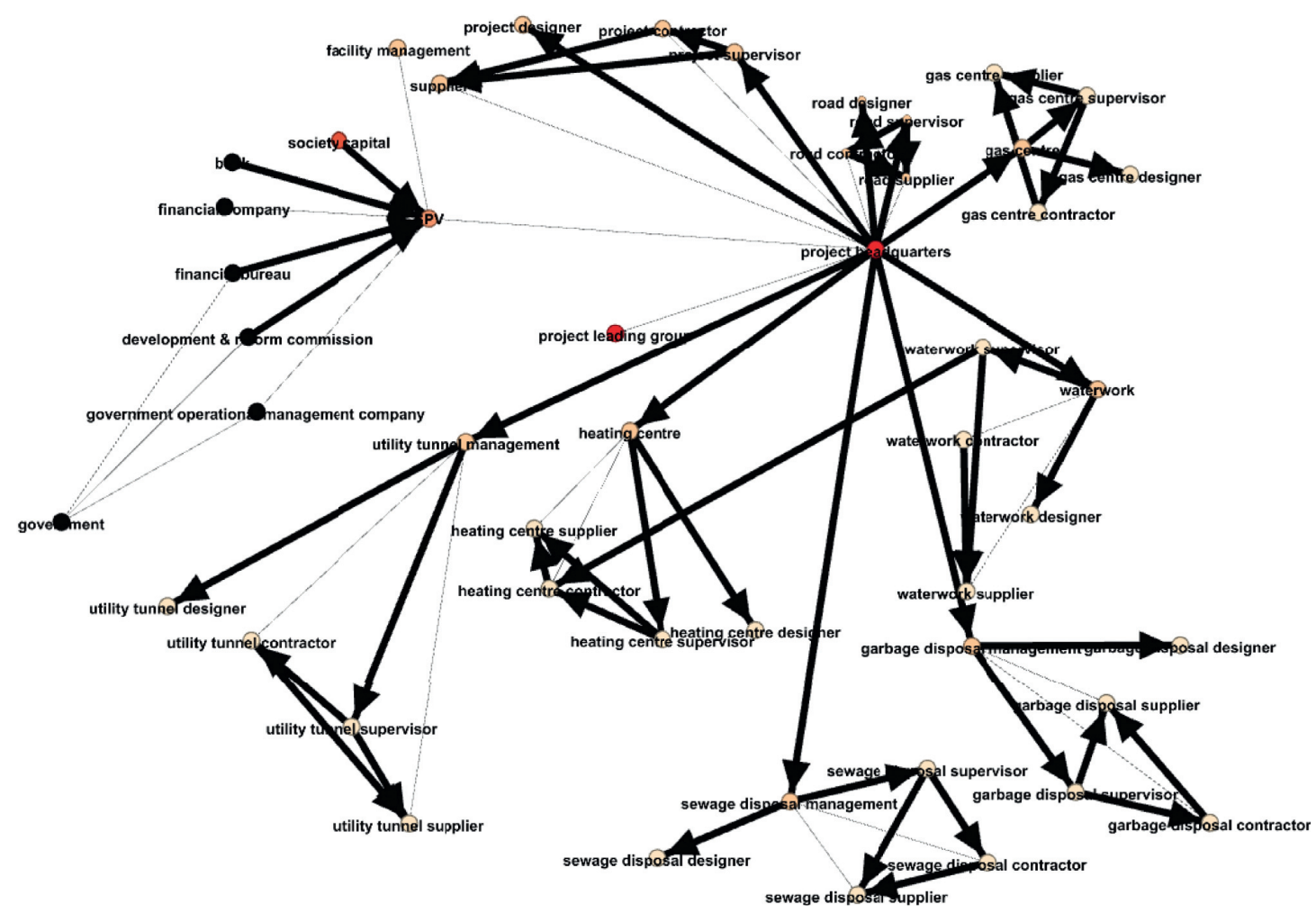

(b)

FIGURE 1: Relationships of project network diagram. (a) CCN diagram. (b) SRN diagram.

greatest authority influence (impacted to) is the SPV followed by project headquarters and facilities management organization. The reason could be that, in the process of project implementation, the project headquarters may replace the SPV to issue orders to contractors and subprojects management organizations, and then the subprojects management organizations will manage and issue an order to their project. On the other hand, the SPV is jointly led by a government operation management company and private partners. The Local Bureau of Finance and Local 
TABLE 3: The rank of influencing power on all stakeholders.

\begin{tabular}{|c|c|c|c|c|c|c|}
\hline $\begin{array}{l}\text { Types of } \\
\text { stakeholders }\end{array}$ & $\begin{array}{l}\text { Work influence } \\
\text { (impacted to) } \\
\text { based on the } \\
\text { degree }\end{array}$ & $\begin{array}{l}\text { Work influence } \\
\text { (impacted by) } \\
\text { based on the } \\
\text { degree }\end{array}$ & $\begin{array}{c}\text { Authority } \\
\text { influence } \\
\text { (impacted to) } \\
\text { based on the } \\
\text { degree }\end{array}$ & $\begin{array}{c}\text { Authority } \\
\text { influence } \\
\text { (impacted by) } \\
\text { based on the } \\
\text { degree }\end{array}$ & $\begin{array}{l}\text { Total work } \\
\text { influence based } \\
\text { on PageRank } \\
\text { algorithm }\end{array}$ & $\begin{array}{c}\text { Total authority } \\
\text { influence based } \\
\text { on PageRank } \\
\text { algorithm }\end{array}$ \\
\hline Private partner & 0.002971768 & 0.002971768 & 0.016 & 0 & 0.005541 & 0.010639 \\
\hline $\begin{array}{l}\text { Government } \\
\text { operations } \\
\text { management } \\
\text { company }\end{array}$ & 0.002971768 & 0.002971768 & 0.016 & 0.008 & 0.009626 & 0.013654 \\
\hline SPV & 0.059435364 & 0.063893016 & 0.016 & 0.088 & 0.064147 & 0.072583 \\
\hline $\begin{array}{l}\text { Local Bureau of } \\
\text { Finance }\end{array}$ & 0.002971768 & 0.002971768 & 0.016 & 0.008 & 0.009626 & 0.013654 \\
\hline $\begin{array}{l}\text { Local Development } \\
\text { and Reform } \\
\text { Commission }\end{array}$ & 0.002971768 & 0.002971768 & 0.016 & 0.008 & 0.009626 & 0.013654 \\
\hline $\begin{array}{l}\text { Project leading } \\
\text { group }\end{array}$ & 0.004457652 & 0.004457652 & 0.008 & 0 & 0.009135 & 0.010639 \\
\hline $\begin{array}{l}\text { Project } \\
\text { headquarters }\end{array}$ & 0.053491828 & 0.054977712 & 0.192 & 0.016 & 0.037419 & 0.050529 \\
\hline $\begin{array}{l}\text { Designing unit of } \\
\text { project }\end{array}$ & 0.019316493 & 0.020802377 & 0 & 0.016 & 0.023126 & 0.01371 \\
\hline Project contractor & 0.028231798 & 0.034175334 & 0.016 & 0.024 & 0.026163 & 0.019534 \\
\hline Project supervisor & 0.026745914 & 0.02526003 & 0.032 & 0.016 & 0.024404 & 0.01371 \\
\hline Bank & 0.001485884 & 0.001485884 & 0.016 & 0 & 0.005541 & 0.010639 \\
\hline $\begin{array}{l}\text { Other enterprises' } \\
\text { financial company }\end{array}$ & 0.001485884 & 0.001485884 & 0.008 & 0 & 0.005541 & 0.010639 \\
\hline Project supplier & 0.02526003 & 0.023774146 & 0 & 0.04 & 0.024404 & 0.03613 \\
\hline $\begin{array}{l}\text { Management unit } \\
\text { of facilities }\end{array}$ & 0.001485884 & 0.001485884 & 0 & 0.008 & 0.005541 & 0.041486 \\
\hline $\begin{array}{l}\text { Sewage waste } \\
\text { management } \\
\text { organization }\end{array}$ & 0.017830609 & 0.022288262 & 0.048 & 0.016 & 0.015083 & 0.01371 \\
\hline $\begin{array}{l}\text { Solid waste } \\
\text { management } \\
\text { organization }\end{array}$ & 0.017830609 & 0.022288262 & 0.048 & 0.016 & 0.015083 & 0.01371 \\
\hline $\begin{array}{l}\text { Water supply } \\
\text { organization }\end{array}$ & 0.017830609 & 0.022288262 & 0.048 & 0.016 & 0.015083 & 0.01371 \\
\hline $\begin{array}{l}\text { Heating } \\
\text { organization }\end{array}$ & 0.017830609 & 0.022288262 & 0.048 & 0.016 & 0.015083 & 0.01371 \\
\hline $\begin{array}{l}\text { Gas supply } \\
\text { organization }\end{array}$ & 0.017830609 & 0.022288262 & 0.048 & 0.016 & 0.015083 & 0.01371 \\
\hline $\begin{array}{l}\text { Utility tunnel } \\
\text { management } \\
\text { organization }\end{array}$ & 0.017830609 & 0.022288262 & 0.048 & 0.016 & 0.015083 & 0.01371 \\
\hline $\begin{array}{l}\text { Designer of sewage } \\
\text { waste facilities }\end{array}$ & 0.016344725 & 0.016344725 & 0 & 0.016 & 0.020785 & 0.013552 \\
\hline $\begin{array}{l}\text { Contractor of } \\
\text { sewage waste } \\
\text { facilities }\end{array}$ & 0.028231798 & 0.028231798 & 0.016 & 0.024 & 0.023821 & 0.01931 \\
\hline $\begin{array}{l}\text { Supervisor of } \\
\text { sewage waste } \\
\text { facilities }\end{array}$ & 0.02526003 & 0.020802377 & 0.032 & 0.016 & 0.022061 & 0.013552 \\
\hline $\begin{array}{l}\text { Supplier of sewage } \\
\text { waste facilities }\end{array}$ & 0.022288262 & 0.022288262 & 0 & 0.04 & 0.022061 & 0.035723 \\
\hline $\begin{array}{l}\text { Designer of solid } \\
\text { waste facilities }\end{array}$ & 0.016344725 & 0.016344725 & 0 & 0.016 & 0.020785 & 0.013552 \\
\hline $\begin{array}{l}\text { Contractor of solid } \\
\text { waste facilities }\end{array}$ & 0.028231798 & 0.028231798 & 0.016 & 0.024 & 0.023821 & 0.01931 \\
\hline $\begin{array}{l}\text { Supervisor of solid } \\
\text { waste facilities }\end{array}$ & 0.02526003 & 0.020802377 & 0.032 & 0.016 & 0.022061 & 0.013552 \\
\hline
\end{tabular}


TABLE 3: Continued.

\begin{tabular}{|c|c|c|c|c|c|c|}
\hline $\begin{array}{l}\text { Types of } \\
\text { stakeholders }\end{array}$ & $\begin{array}{c}\text { Work influence } \\
\text { (impacted to) } \\
\text { based on the } \\
\text { degree }\end{array}$ & $\begin{array}{l}\text { Work influence } \\
\text { (impacted by) } \\
\text { based on the } \\
\text { degree }\end{array}$ & $\begin{array}{l}\text { Authority } \\
\text { influence } \\
\text { (impacted to) } \\
\text { based on the } \\
\text { degree }\end{array}$ & $\begin{array}{l}\text { Authority } \\
\text { influence } \\
\text { (impacted by) } \\
\text { based on the } \\
\text { degree }\end{array}$ & $\begin{array}{c}\text { Total work } \\
\text { influence based } \\
\text { on PageRank } \\
\text { algorithm }\end{array}$ & $\begin{array}{c}\text { Total authority } \\
\text { influence based } \\
\text { on PageRank } \\
\text { algorithm }\end{array}$ \\
\hline $\begin{array}{l}\text { Supplier of solid } \\
\text { waste facilities }\end{array}$ & 0.022288262 & 0.022288262 & 0 & 0.04 & 0.022061 & 0.035723 \\
\hline $\begin{array}{l}\text { Designer of water } \\
\text { supply facilities }\end{array}$ & 0.016344725 & 0.016344725 & 0 & 0.016 & 0.020785 & 0.013552 \\
\hline $\begin{array}{l}\text { Contractor of } \\
\text { water supply } \\
\text { facilities }\end{array}$ & 0.028231798 & 0.028231798 & 0.016 & 0.008 & 0.023821 & 0.013552 \\
\hline $\begin{array}{l}\text { Supervisor of water } \\
\text { supply facilities }\end{array}$ & 0.02526003 & 0.020802377 & 0.032 & 0.016 & 0.022061 & 0.013552 \\
\hline $\begin{array}{l}\text { Supplier of water } \\
\text { supply facilities }\end{array}$ & 0.022288262 & 0.022288262 & 0 & 0.04 & 0.022061 & 0.030826 \\
\hline $\begin{array}{l}\text { Designer of heating } \\
\text { systems }\end{array}$ & 0.016344725 & 0.016344725 & 0 & 0.016 & 0.020785 & 0.013552 \\
\hline $\begin{array}{l}\text { Contractor of } \\
\text { heating systems }\end{array}$ & 0.028231798 & 0.028231798 & 0.016 & 0.04 & 0.023821 & 0.025068 \\
\hline $\begin{array}{l}\text { Supervisor of } \\
\text { heating systems }\end{array}$ & 0.02526003 & 0.020802377 & 0.032 & 0.016 & 0.022061 & 0.013552 \\
\hline $\begin{array}{l}\text { Supplier of heating } \\
\text { systems }\end{array}$ & 0.022288262 & 0.022288262 & 0 & 0.04 & 0.022061 & 0.04062 \\
\hline $\begin{array}{l}\text { Designer of gas } \\
\text { supply facilities }\end{array}$ & 0.016344725 & 0.016344725 & 0 & 0.016 & 0.020785 & 0.013552 \\
\hline $\begin{array}{l}\text { Contractor of gas } \\
\text { supply facilities }\end{array}$ & 0.028231798 & 0.028231798 & 0.016 & 0.024 & 0.023821 & 0.01931 \\
\hline $\begin{array}{l}\text { Supervisor of gas } \\
\text { supply facilities }\end{array}$ & 0.02526003 & 0.020802377 & 0.032 & 0.016 & 0.022061 & 0.013552 \\
\hline $\begin{array}{l}\text { Supplier of gas } \\
\text { supply facilities }\end{array}$ & 0.022288262 & 0.022288262 & 0 & 0.04 & 0.022061 & 0.035723 \\
\hline $\begin{array}{l}\text { Designer of utility } \\
\text { tunnel }\end{array}$ & 0.016344725 & 0.016344725 & 0 & 0.016 & 0.020785 & 0.013552 \\
\hline $\begin{array}{l}\text { Contractor of } \\
\text { utility tunnel }\end{array}$ & 0.028231798 & 0.028231798 & 0.016 & 0.024 & 0.023821 & 0.01931 \\
\hline $\begin{array}{l}\text { Supervisor of } \\
\text { utility tunnel }\end{array}$ & 0.02526003 & 0.020802377 & 0.032 & 0.016 & 0.022061 & 0.013552 \\
\hline $\begin{array}{l}\text { Supplier of utility } \\
\text { tunnel }\end{array}$ & 0.022288262 & 0.022288262 & 0 & 0.04 & 0.022061 & 0.035723 \\
\hline Government & 0.007429421 & 0.005943536 & 0.024 & 0 & 0.019206 & 0.010639 \\
\hline $\begin{array}{l}\text { Designer of } \\
\text { industrial park } \\
\text { road }\end{array}$ & 0.019316493 & 0.017830609 & 0 & 0.016 & 0.023126 & 0.01371 \\
\hline $\begin{array}{l}\text { Contractor of } \\
\text { industrial park } \\
\text { road }\end{array}$ & 0.031203566 & 0.026745914 & 0.016 & 0.024 & 0.026163 & 0.019534 \\
\hline $\begin{array}{l}\text { Supervisor of } \\
\text { industrial park } \\
\text { road }\end{array}$ & 0.029717682 & 0.022288262 & 0.032 & 0.016 & 0.024404 & 0.01371 \\
\hline $\begin{array}{l}\text { Supplier of } \\
\text { industrial park } \\
\text { road }\end{array}$ & 0.019316493 & 0.023774146 & 0 & 0.04 & 0.024404 & 0.03613 \\
\hline
\end{tabular}

Development and Reform Commission will supervise the behavior of the SPV and the SPV's financial funds use is also supervised by the bank and other enterprises' financial companies. In addition, all suppliers have to meet requirements for contractors and supervisors. In reality, the project headquarters should still report the progress of project implementation to the SPV. In other words, the SPV is the most influential (impacted to) stakeholder for project decisions actually, which confirmed the results of the PageRank algorithm method. The SPV has multi-dimensional leadership and thus its power is higher than its upper management stakeholders. As the directed manager, the project headquarters are the second influential (impacted to) stakeholder for authority influence. In addition, the facilities 
TABLE 4: Comparison of the stakeholders' influence before and after the direct management of regulators and financial institutions.

\begin{tabular}{|c|c|c|c|c|c|c|}
\hline \multirow[b]{2}{*}{ Stakeholders } & \multicolumn{3}{|c|}{$\begin{array}{c}\text { Before the direct management of regulators and financial } \\
\text { institutions }\end{array}$} & \multicolumn{3}{|c|}{$\begin{array}{c}\text { After the direct management of regulators and financial } \\
\text { institutions }\end{array}$} \\
\hline & $\begin{array}{c}\text { Authority } \\
\text { influence } \\
\text { (impacted to) } \\
\text { based on the } \\
\text { degree }\end{array}$ & $\begin{array}{l}\text { Authority } \\
\text { influence } \\
\text { (impacted by) } \\
\text { based on the } \\
\text { degree }\end{array}$ & $\begin{array}{c}\text { Total work } \\
\text { influence based } \\
\text { on PageRank } \\
\text { algorithm }\end{array}$ & $\begin{array}{c}\text { Authority } \\
\text { influence } \\
\text { (impacted to) } \\
\text { based on the } \\
\text { degree }\end{array}$ & $\begin{array}{c}\text { Authority } \\
\text { influence } \\
\text { (impacted by) } \\
\text { based on the } \\
\text { degree }\end{array}$ & $\begin{array}{l}\text { Total work } \\
\text { influence based } \\
\text { on PageRank } \\
\text { algorithm }\end{array}$ \\
\hline SPV & 0.016 & 0.088 & 0.072583 & 0.051 & 0.064 & 0.036604 \\
\hline $\begin{array}{l}\text { Project } \\
\text { headquarters }\end{array}$ & 0.192 & 0.016 & 0.050529 & 0.154 & 0.026 & 0.026372 \\
\hline $\begin{array}{l}\text { Local Bureau of } \\
\text { Finance }\end{array}$ & 0.016 & 0.008 & 0.013654 & 0.0577 & 0.006 & 0.013592 \\
\hline $\begin{array}{l}\text { Local Development } \\
\text { and Reform } \\
\text { Commission }\end{array}$ & 0.016 & 0.008 & 0.013654 & 0.0577 & 0.006 & 0.013592 \\
\hline Bank & 0.016 & 0 & 0.010639 & 0.0513 & 0 & 0.010592 \\
\hline $\begin{array}{l}\text { Other enterprises' } \\
\text { financial company }\end{array}$ & 0.008 & 0 & 0.010639 & 0.0449 & 0 & 0.010592 \\
\hline $\begin{array}{l}\text { Sewage waste } \\
\text { management } \\
\text { organization }\end{array}$ & 0.048 & 0.016 & 0.01371 & 0.0384 & 0.0449 & 0.021544 \\
\hline $\begin{array}{l}\text { Solid waste } \\
\text { management } \\
\text { organization }\end{array}$ & 0.048 & 0.016 & 0.01371 & 0.0384 & 0.0449 & 0.021544 \\
\hline $\begin{array}{l}\text { Water supply } \\
\text { organization }\end{array}$ & 0.048 & 0.016 & 0.01371 & 0.0384 & 0.0449 & 0.021544 \\
\hline $\begin{array}{l}\text { Heating } \\
\text { organization }\end{array}$ & 0.048 & 0.016 & 0.01371 & 0.0384 & 0.0449 & 0.021544 \\
\hline $\begin{array}{l}\text { Gas supply } \\
\text { organization }\end{array}$ & 0.048 & 0.016 & 0.01371 & 0.0384 & 0.0449 & 0.021544 \\
\hline $\begin{array}{l}\text { Utility tunnel } \\
\text { management } \\
\text { organization }\end{array}$ & 0.048 & 0.016 & 0.01371 & 0.0384 & 0.0449 & 0.021544 \\
\hline
\end{tabular}

management organization has a close connection with the SPV and thus its suggestions have an influence on subordinate organizations through the SPV. Therefore, the facilities management organization is the third influential (impacted to) stakeholder for authority influence. Taken together, the results, based on the method of PageRank algorithm, are consistent with the authority influence facts and another result based on the degree is more consistent with authority influence presentation.

\section{Discussion}

This study builds the social network based on stakeholders' characteristics of the PPP program in China. Results show that the SPV is considered the core of CCN and SRN, which comply with Peng's study on American Expressway PPP projects but the divergence still appeared. The SPV has the greatest social influence on the project, which corroborates Peng's study that the SPV and state agencies are the greatest. On the other hand, the project headquarters and SPV have the greatest authority influence in terms of degree and PageRank algorithm, respectively, which is contrary to Peng's results towards state agencies [20]. The above comparative analysis shows that the stakeholders involved in the program are closer. There are two main points about the reason for the independence of the organization's supervision: one is the view of organizational complexity which causes the organizational isolation [23], and the other is the view of the stakeholders who are inclined to transfer the incomplete information and knowledge for ensuring informational asymmetry within a project [24]. Together with the CCN, the SPV and project headquarters have the greatest authority, which confirms the above two views.

The results support the idea that the regulator, including the Local Development and Reform Commission and Local Bureau of Finance, and financial institutions such as banks and other enterprises' financial parties, has less influence on SRN of a project than the SPV and project headquarters. The government regulator focuses on project progress and financials; however, the financial institution mainly pays attention to the financial. Therefore, the organizational structure of program governance should be improved: the project headquarters and subprojects management organizations should report to the Local Bureau of Finance and Local Development and Reform Commission; the subprojects management organizations have to report to the bank and other enterprises' financial company. The stakeholders' influence of improved organizational structure is presented in Table 4. The findings also suggested that the Local Bureau of Finance, Local Development and Reform 
Commission, bank, and other enterprises' financial parties have remarkably improved their authority influence (impacted to) based on the degree method. The project headquarters and subprojects management organizations also improved their authority influence (impacted by) based on the degree method. In addition, in terms of PageRank algorithm, supposing that the total authority influence of Local Bureau of Finance, Local Development and Reform Commission, bank, and other enterprises' financial company remains unchanged, the results revealed that the SPV and project headquarters have a rapid decline in its total authority influence; however, the influence of the subprojects management organizations is rising. Therefore, the subprojects management organizations could narrow the influence gap with the SPV and project headquarters rapidly and have a restrictive effect on the SPV and project headquarters. These findings are in accord with the study of Yang et al. [25] that pulling closer the governance distance contributes to the decentralization of management organization and helps the regulator and financial institution to supervise the program.

\section{Conclusions}

Three main conclusions can be drawn from the present study. Firstly, the SPV is the core stakeholder in the construction phase of the PPP program and also occupies the central position in the communication and cooperation networks and supervisory relationship networks. In addition, the influence of the SPV in the program determines the quality of construction and operation. Secondly, CCN and SRN are characterized by obvious narrow networks. During the construction phase of the PPP program, the supervision still has hierarchical characteristics. The top supervision is not closely connected with the substrate supervision due to their small world. In other words, there is a chance for the middle supervision and substrate supervision to collude and deceive the SPV and project headquarters. Thirdly, the government regulators and loan institutions have limited influences on the program but are able to restrict the SPV by strengthening supervision with subprogram stakeholders.

6.1. Managerial Implications. Firstly, there is a little empirical study about the impact of program organizational scale on organizational management methods. This study uses a case study to reveal the necessity of research on crossproject and cross-organizational collective governance of 49 stakeholders in 8 interrelated projects, which covers multiple hierarchy projects, and each project covers multiple hierarchy stakeholders [19]. Based on the results of this study, as the highest centrality of stakeholders, SPV company's adjacency centrality is only 0.6486 in the communication and cooperation network, while that in the supervision network is 0.392 . Due to the large scale of organization, there are still some communication and regulatory barriers between the stakeholders of the project and other stakeholders in the multi-program group [26]. Most of the stakeholders in the network bottom are still unconnected with each other, and their information channels are still mainly monopolized by the program management organizations (including SPV company). Information asymmetry makes the network bottom stakeholders' behaviors repeated and uncoordinated.

Secondly, the complexity of project group governance lies not only in the complexity of behavior governance but also in the complexity of governance on the unique communication and supervision structure of the program group. The unique structure of the program group determines the unequal rights and obligations of multi-stakeholders. Due to the feedback lag of the supervision network and the longdistance management of core stakeholders (SPV company), program group governance is more dependent on the selfdiscipline and autonomy of program stakeholders, rather than the incentive and punishment of traditional management [27].

6.2. Practical Implications. Firstly, the SPV of the PPP program should enhance talent multi-disciplinary training and construct an interdisciplinary talent team with members from the government investment department, government regulators, private partners, and project construction units. At the project implementation stage, the SPV needs to communicate with the government investment department and private partners, to meet the regulatory requirements by the government regulators, and assist the project headquarters in managing projects. Therefore, the SPV should establish long-term, stable cooperation with these departments so that the situation will be sorted out in time. In addition, hierarchical governance was adopted during different stages including project decisions, conflicts, interests, and obligations, which strengthens the multi-stakeholder governance and reduces misunderstandings and mistrusts resulting from the information asymmetry among stakeholders.

Secondly, the SPV with low network density has less effective communication with the implementing parties of the project, which causes the omission and distortion of bottom-up information transfer and brings risks of decision deviation. Therefore, in order to reduce these risks, the SPV, as a spectator, may participate in the meetings of projects held by the project headquarters and subproject management organizations, which helps the SPV be aware of the actual situation of the project and make more contacts with other stakeholders so as to make up for the low density of power network by increasing the density of work communication network.

Thirdly, the SPV should strengthen collaborative management with project headquarters. In general, the project headquarters are responsible for special content of the project construction and management; however, only the overall progress was introduced to the SPV, which could neither meet the regulatory requirements of SPV and operation requirements by facilities management organization nor understand the strategic intention of project headquarters. Therefore, the SPV should participate in the meetings held by the project headquarters, conduct more 
communication, and work together with the project headquarters actively.

Fourthly, the government regulators and loan institutions have limited influence on implantation stages of the PPP program at present, who supervise not only the SPV but also other stakeholders such as the project headquarters and subproject management organizations. In this way, it can reduce the control of the project headquarters and subproject management organizations, form the multi-stakeholder governance, and help the project headquarters and subproject management organizations be aware of the project progress and fulfill their responsibility.

Finally, to match the incentives and events, a communication and cooperation relationship should be formed between the project headquarters and SPV in the incentive process of the program, which can integrate the regulatory functions of project headquarters and the cash flow management responsibilities of SPV. In addition, the project headquarters and SPV should have more work communication with other stakeholders so that they can reduce the indirect incentives through intermediary stakeholders and increase direct incentives.

6.3. Limitation and Future Research. Despite this study's contributions, two research limitations need to be acknowledged. First, the author was not able to build a dynamic network based on different stages of the life cycle due to the limited research circle. During different stages, the degree of communication and cooperation was different between various stakeholders. Therefore, future research might build a dynamic network in different stages. Second, there is no direct demonstration of the formation and transmission mechanism for regulatory isolation of the program organization, which should be highlighted in future research.

In the future, dynamic simulation technology and artificial intelligence technology can be used to study the dynamic evolution of stakeholders in the PPP project group's social network [28-35] and to reveal the organizational governance dynamic evolution mechanism. In particular, the stakeholders from SPV company should be focused on. Further research will discuss the core competence, risk factors, and risk mitigation mechanism of the SPV company that matches its governance status in program governance. The interaction mechanism of governance behavior and governance structure is also an important direction for future research [27].

\section{Data Availability}

The data used to support the findings of the study can be made available upon request.

\section{Conflicts of Interest}

The author declares that there are no conflicts of interest.

\section{Acknowledgments}

This work was supported by the Beijing Philosophy and Social Science Fund (grant number: 17GLC057); the Basic
Scientific Research Fund of Beijing Municipal Colleges (grant numbers: X18174 and ZF17046); and the Pyramid Talent Training Project of Beijing University of Civil Engineering and Architecture.

\section{Supplementary Materials}

This questionnaire describes the relationship between different stakeholders to construct the communication and cooperation networks and supervisory relationship networks. It is hard to describe the relationship between someone to others. However, this study uses communication frequency to measure communication and cooperation and uses supervisor and supervisee interactive relationship to measure supervisory relationship. The interviewer needs to evaluate his/her stakeholder to others relationship by his/her working experience. (Supplementary Materials)

\section{References}

[1] Q. Mai, Y. Zhao, and S. An, "Discrete decision model and multi-agent simulation of the Liang Zong two-chain hierarchical organization in a complex project," Journal of Systems Engineering and Electronics, vol. 29, no. 2, pp. 311-320, 2018.

[2] Z. Zhai, T. Ahola, Y. Le, and J. Xie, "Governmental governance of megaprojects: the case of EXPO 2010 Shanghai," Project Management Journal, vol. 48, no. 1, pp. 37-50, 2017.

[3] J. Xie and Y. Qiu, "Complex integrity and the improved DB mode in infrastructure mega-projects: how does the improved DB mode degrade the complex integrity of infrastructure mega-projects? Evidence from the Hong Kong-ZhuhaiMacau bridge project in China," Frontiers of Engineering Management, vol. 5, no. 1, pp. 40-51, 2018.

[4] T. Yu, X. Liang, G. Q. Shen, Q. Shi, and G. Wang, "An optimization model for managing stakeholder conflicts in urban redevelopment projects in China," Journal of Cleaner Production, vol. 212, pp. 537-547, 2019.

[5] T. Ahola, I. Ruuska, K. Artto, and J. Kujala, "What is project governance and what are its origins?" International Journal of Project Management, vol. 32, no. 8, pp. 1321-1332, 2014.

[6] C. Kujala, P. Fewings, and P. D. Rwelamila, "De-marginalising the public in PPP projects through multi-stakeholders management," Journal of Financial Management of Property and Construction, vol. 18, no. 3, pp. 210-231, 2013.

[7] S. Olander and A. Landin, "Evaluation of stakeholder influence in the implementation of construction projects," International Journal of Project Management, vol. 23, no. 4, pp. 321-328, 2005.

[8] K. Sha, Ten Lectures on Construction Project Governance, China Architecture and Building Press, Beijing, China, 1st edition, 2017.

[9] K. Sha, "Analysis of construction project level governance based on alliance game theory," Project Management Technology, vol. 9, no. 11, pp. 33-39, 2011.

[10] Y. E. A. Yin, "Theoretical integration study on public project contract management and relationship management," Science \& Technology Progress and Policy, vol. 28, no. 13, pp. 1-4, 2011.

[11] W. J. Henisz, R. E. Levitt, and W. R. Scott, "Toward a unified theory of project governance: economic, sociological and psychological supports for relational contracting," Engineering Project Organization Journal, vol. 2, no. 1-2, pp. 37-55, 2012. 
[12] E. G. Too and P. Weaver, "The management of project management: a conceptual framework for project governance," International Journal of Project Management, vol. 32, no. 8, pp. 1382-1394, 2014.

[13] T. J. Rowley, "Moving beyond dyadic ties: a network theory of stakeholder influences," Academy of Management Review, vol. 22, no. 4, pp. 887-910, 1997.

[14] R. J. Yang and P. X. W. Zou, "Stakeholder-associated risks and their interactions in complex green building projects: a social network model," Building and Environment, vol. 73, pp. 208-222, 2014.

[15] J. Wang, R. Ding, and L. Wang, "Study on the impact of features of project stakeholder social network on the performance of science innovation project," Forum on Science and Technology in China, vol. 32, no. 5, pp. 18-24, 2016.

[16] E.-H. Klijn, J. Edelenbos, and B. Steijn, "Trust in governance networks: its impact on outcomes," Administration \& Society, vol. 42, no. 2, pp. 193-221, 2010.

[17] R. Ding, L. Fang, S. Tao et al., "The study on project governance based on social network analysis-an example of large construction project supervision," China Soft Science, vol. 25, no. 6, pp. 132-140, 2010.

[18] W. Lei, D. Ronggui, C. Qian et al., "Comparison governance of two types of ITRI's collaborative innovation projects-research on social network analysis method," Science \& Technology Progress and Policy, vol. 33, no. 12, pp. 1-7, 2016.

[19] J. Lienert, F. Schnetzer, and K. Ingold, "Stakeholder analysis combined with social network analysis provides fine-grained insights into water infrastructure planning processes," Journal of Environmental Management, vol. 125, pp. 134-148, 2013.

[20] P. Wei, C. Jianguo, W. Di et al., "Stakeholder influence analysis of public-private partnership projects from the perspective of communication, workflow and contract," Management Review, vol. 29, no. 5, pp. 205-215, 2017.

[21] Z. Chen, Q. He, Y. Lee et al., "Citizenship behavior definition of large-scale public projects and scale development in China," East China Economic Management, vol. 30, no. 2, pp. 107-113, 2016.

[22] D. A. S. Y. Knoke, Social Network Analysis, Sage Publications, Thousand Oaks, CA, USA, 2019.

[23] R. Olsson, "In search of opportunity management: is the risk management process enough?" International Journal of Project Management, vol. 25, no. 8, pp. 745-752, 2007.

[24] R. M. Bakker, B. Cambré, L. Korlaar, and J. Raab, "Managing the project learning paradox: a set-theoretic approach toward project knowledge transfer," International Journal of Project Management, vol. 29, no. 5, pp. 494-503, 2011.

[25] Y. Yang, F. Wang, and C. Sun, "Allocation of decision rights in business groups-from the perspective of parent-subsidiary governance distance," China Industrial Economics, vol. 32, no. 1, pp. 108-120, 2015.

[26] H. Aladag and Z. Isik, "The effect of stakeholder-associated risks in mega-engineering projects: a case study of a PPP airport project," IEEE Transactions on Engineering Management, vol. 67, no. 1, pp. 174-186, 2020.

[27] C. Benítez-Ávila, A. Hartmann, and G. Dewulf, "Contractual and relational governance as positioned-practices in ongoing public-private partnership projects," Project Management Journal, vol. 50, no. 6, pp. 716-733, 2019.

[28] X. Xu and H.-L. Chen, "Adaptive computational chemotaxis based on field in bacterial foraging optimization," Soft Computing, vol. 18, no. 4, pp. 797-807, 2014.

[29] H. Chen, Q. Zhang, J. Luo, Y. Xu, and X. Zhang, "An enhanced bacterial foraging optimization and its application for training kernel extreme learning machine," Applied Soft Computing, vol. 86, Article ID 105884, 2020.

[30] X. Xu, X. Zhang, Z. Cai et al., "Chaos enhanced grey wolf optimization wrapped ELM for diagnosis of paraquat-poisoned patients," Computational Biology and Chemistry, vol. 78, pp. 481-490, 2019.

[31] M. Tian and H. Chen, "Chaotic multi-swarm whale optimizer boosted support vector machine for medical diagnosis," Applied Soft Computing, vol. 88, Article ID 105946, 2019.

[32] Y. Xu, H. Chen, J. Luo, Q. Zhang, S. Jiao, and X. Zhang, "Enhanced Moth-flame optimizer with mutation strategy for global optimization," Information Sciences, vol. 492, pp. 181203, 2019.

[33] L. Zhang, H. Chen, Z. Yu et al., "Evolving support vector machines using fruit fly optimization for medical data classification," Knowledge-Based Systems, vol. 96, pp. 61-75, 2016.

[34] X. Zhao, D. Li, B. Yang, C. Ma, Y. Zhu, and H. Chen, "Feature selection based on improved ant colony optimization for online detection of foreign fiber in cotton," Applied Soft Computing, vol. 24, pp. 585-596, 2014.

[35] M. Wang, H. Chen, B. Yang et al., "Toward an optimal kernel extreme learning machine using a chaotic moth-flame optimization strategy with applications in medical diagnoses," Neurocomputing, vol. 267, pp. 69-84, 2017. 